\title{
EDUKASI MANFAAT JUS WORTEL SEBAGAI TERAPI DISMENOREA PADA REMAJA
}

\author{
Sunarsih $^{1^{*}}$, Aryati Sumarlinda ${ }^{2}$, Fijri Rachmawati ${ }^{3}$ \\ 1,3Prodi Kebidanan Universitas Malahayati \\ 2Puskesmas Mulya Asri
}

Email Korespondensi: sunarsih@malahayati.ac.id

\begin{abstract}
ABSTRAK
Dismenore adalah nyeri ringan yang dapat ditolerir tanpa obat, namun dalam kondisi berat bisa mengganggu aktivitas sehari - hari atau absen sekolah. Pemicu utama dismenore primer adalah prostaglandin yang berperan penting menyebabkan kram dan kontraksi serta gejala lainnya. Mengatasi dismenore dapat dilakukan dengan menggunakan jus wortel yang kaya akan karotin, pectin, aspargin, serat, lemak, hidrat arang, kalsium, fosfor, besi, sodium, asam amino, minyak esensial dan beta karote serta vitamin A,B,C,D,E dan K. Vitamin E membantu block formasi prostaglandin dan membantu mengatasi efek dari peningkatan prostaglandin, sehingga efektif menurunkan nyeri. Kegiatan penyuluhan dilakukan di wilayah kerja Puskesmas Mulya Asri tanggal 15 maret 2021. Kegiatan diawali dengan melakukan pertest lalu penyampaian materi, demonstrasi pembuatan jus dan diakhiri dengan evalusi dalam bentuk post test. Terdapat peningkatan pengetahuan remaja putri tentang dismenore serta cara mengatasi dismenorea menggunakan jus wortel yaitu sebesar $55 \%$.
\end{abstract}

Kata Kunci: Edukasi, Jus Wortel, Remaja, Dismenore

\begin{abstract}
Dysmenorrhea is mild pain which can be tolerated without medicine, however in severed condition can disturb daily activity or absent in the school. The main trigger of primer dysmenorrhea is prostaglandin that has important role in causing cramps, contraction and other symptoms. The way to overcome dysmenorrhea can be done by using carrot juice in which very rich of carotene, pectin, asparagine, fiber, fat, carbohydrate, calcium, phosphorus, iron, Sodium, amino acids, essential oil, beta carotene and $A, B, C, D, E, K$ vitamin. Vitamin $E$ helps block formation of prostaglandin and helps in overcoming the effects of increased prostaglandin, so that it is very effective in decreasing the pain. Counseling activity was done in worked area of Mulya Asri's Public Health Center on $15^{\text {th }}$ March 2021. This activity was started by doing pretest, delivering the material, demonstrating in making juice and ended by evaluating in the form of posttest. The results were the teenage girls have had increased their knowledge about dysmenorrhea and they have had known in overcoming dysmenorrhea by using carrot juice totally $55 \%$.
\end{abstract}

Key words : Education, Carrot Juice, teenage, Dysmenorrhea 


\section{PENDAHULUAN}

Dismenore adalah nyeri siklik yang terjadi waktu haid dan merupakan masalah sosial ekonomi. Dismenore disebut ringan bila nyeri dapat ditoleransi tanpa obat, dismenore sedang bila memerlukan obat, dan dismenore berat bila sampai mengganggu pekerjaan sehari - hari seperti tidak masuk kerja atau absen sekolah (Akbar dkk, 2020).

Angka kejadian dismenore pada remaja di Asia adalah 74,5\%. Pada remaja putri hispanic prevalensi dismenore sebesar $85 \%$. Sedangkan angka kejadian di Indonesia adalah 55\%. Melihat data tersebut dapat diartikan bahwa hampir semua wanita mengalami dismenore (Heni \& Kp, 2018)

Terdapat dua jenis dismenore yaitu primer dan sekunder. Pada kalangan remaja, dismenore yang lazim terjadi adalah dismenore primer. Pemicu utama dismenore primer adalah prostaglandin, zat kimia tubuh yang dapat menyebabkan kram atau kontraksi. Pada jumlah yang berlebih, dapat menyebabkan: mual, muntah, sakit kepala, nyeri punggung, diare, dan kram yang parah pada saat menstruasi (Priyatna,2013)

Mengatasi dismenorea dapat dilakukan dengan penjelasan dan nasihat, pemberian obat analgetik, terapi hormonal, terapi alternative (Judha, 2012: Puspita, 2018). Menurunkan tingkat nyeri dismenorea sebaiknya menggunakan obat tradisional yang sedikit efek sampingnya bahkan tidak ada, salah satu cara non farmakologi adalah wortel. Namun belum banyak yang menggunakan wortel untuk mengatasi nyeri haid.

Wortel (Daucus Carota) merupakan salah satu sayuran yang paling banyak manfaatnya. Wortel mengandung gula, karotin, pectin, aspargin, serat, lemak, hidrat arang, kalsium, fosfor, besi, sodium, asam amino, minyak esensial dan beta karoten. Wortel mengandung vitamin A,B,C,D,E dan K (Al-Snafi, 2018). Salah satu manfaat vitamin $\mathrm{E}$ adalah membantu block formasi prostaglandin dan membantu mengatasi efek dari peningkatan prostaglandin tersebut. Hormon prostaglanding adalah hormon yang mempengaruhi dismenore, dalam hal ini yang berperan adalah prostaglandin E2 (PGE2) dan $\mathrm{E}_{2 a}\left(\mathrm{PDF}_{2 a}\right)$ (Puspita, 2018: Latifah dkk,2021)

Konsumsi Vitamin E dapat menurunkan tingkat nyeri dan dapat mengurangi banyaknya darah haid yang berlebihan, hal ini dilakukan dengan cara menyeimbangkan hormon dalam tubuh sehingga siklus menstruasi dapat teratur. Vitamin B1 (Thiamine), B6 dan E mampu mengurangi nyeri menstruasi sehingga bahan makanan yang mengandung vitamin tersebut seperti wortel sebaiknya dikonsumsi untuk mengurangi dismenore (Barklet, 2013: Affandy, 2021).

Dismenore merupakan salah satu komponen kesehatan reproduksi. Pemahanan tentang pengaruh kesehatan reproduksi terhadap kesehatan belum dipahami secara luas. Hal ini disebabkan oleh kurangnya informasi yang benar mengenai kesehatan reproduksi. Kekurangan informasi terjadi salah satunya pada kalangan remaja (Emilia \& Prabandari, 2019). Oleh sebab itu, solusi yang tepat untuk mengatasi masalah tersebut adalah dilakukannya penyuluhan kesehatan. Penyuluhan kesehatan merupakan upaya peningkatan kesadaran dan pengetahuan disamping sikap dan perbuatan. Makna asli penyuluhan adalah pemberian penerangan dan informasi, maka setelah dilakukan penyuluhan kesehatan, hendaknya dapat terjadi peningkatan pengetahuan oleh masyarakat (Hartati \& Apriani, 2020). 


\section{MASALAH}

Kegiatan penyuluhan dilakukan di wilayah kerja Puskesmas Mulya Asri dikarenakan terdapat 10 remaja mengeluhkan nyeri saat menstruasi dan 2 orang diantaranya membutuhkan istirahat total sehingga tidak dapat melakukan aktivitasnya sehari - hari. Selain itu pengetahuan remaja tentang terapi nonfarmakologi sangat minim, selama ini penanganan dismenore dilakukan dengan mengkonsumsi analgesik atau obat yang dapat dibeli di warung. Tujuan khusus dari kegiatan edukasi ini adalah remaja mengerti dan mampu melakukan penanganan dismenore secara non farmakologi yang aman dan efektif salah satunya dengan mengkonsumsi jus wortel.

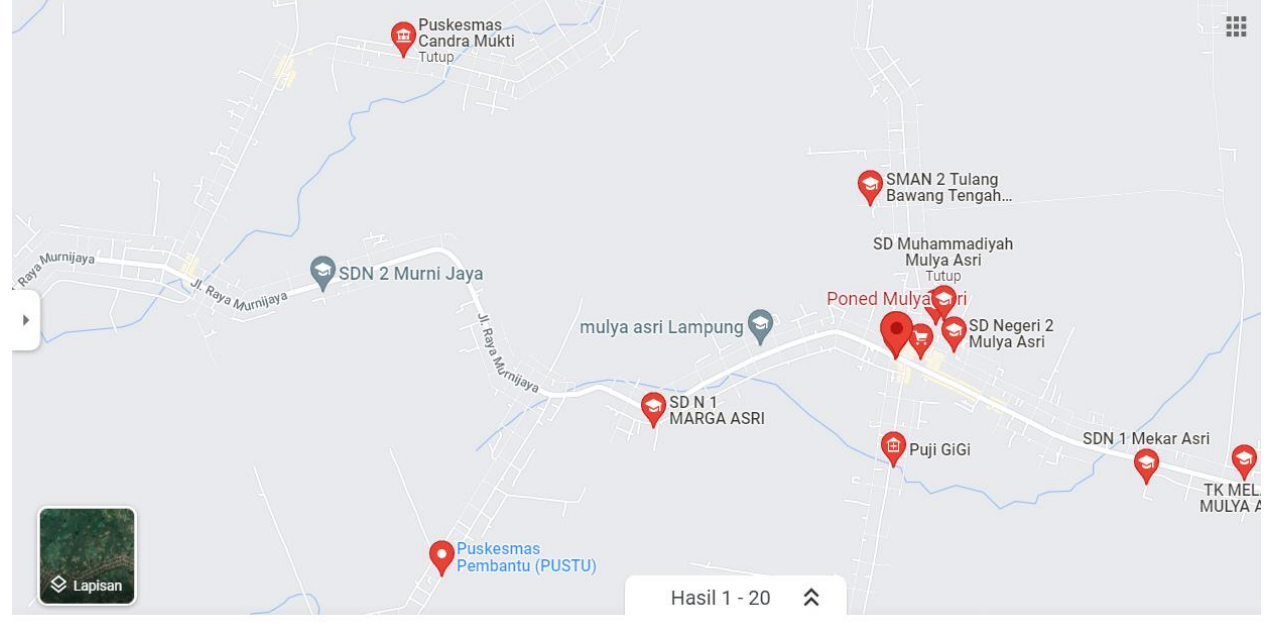

Gambar 2.1 Peta Lokasi Kegiatan Pengabdian Kepada Masyarakat

\section{METODE}

a. Tujuan Persiapan

Tujuan Persiapan dari kegiatan adalah pembuatan pre planning kegiatan penyuluhan berupa pembuatan dan pengajuan surat izin, persiapan tempat serta alat-alat lainnya yang disiapkan oleh tim pengabdian masyarakat baik dari Institusi pendidikan dan di Puskesmas Mulya Asri dimulai pada tanggal 10 Maret 2021. Pembuatan materi, standar operasional prosedur pembuatan jus wortel dan leaflet dilakukan pada tanggal 13 Maret 2021.

b. Tahap Pelaksanaan

Kegiatan ini dimulai dengan mengumpulkan remaja putri yang mengalami dismenore oleh salah satu tim penyuluh yang merupakan tenaga kesehatan di Puskemas Mulya Asri. Penyuluhan dilakukan dengan memperhatikan protokol kesehatan, kegiatan dibagi menjadi 2 sesi masing -masing sesi diikuti oleh 5 peserta. Sebelum penyuluhan dimulai, tim melakukan prestest dan didapatkan hanya 35\% remaja yang mengetahui tentang dismenore. Setalah pretest Lalu dilanjutkan dengan memberikan edukasi tentang dismenore serta manfaat jus wortel sebagai salah satu terapi nonfarmakologi yang efektif. Pada tahap akhir pelaksanaan, remaja diajarkan cara membuat jus wortel sesuai dengan standar operasional prosedur yang sudah disiapkan sebelumnya dan kegiatan ditutup dengan evaluasi dalam bentuk post test. 
c. Evaluasi

1. Struktur

Kegiatan dihadiri oleh 10 remaja putri di wilayah kerja Puskesmas Mulya Asri yang mengalami dismenore. Setting tempat sudah sesuai dengan rencana, dengan memperhatikan jarak aman, perlengkapan dan peralatan yang sudah tersedia digunakan sebagaimana mestinya. Remaja antusias dalam mengikuti penyuluhan. Materi disampaikan dengan bahasa Indonesia yang mudah dimengerti. Materi tersampaikan dengan baik, dapat diterima dan dipahami oleh remaja sebagai audien.

2. Proses Pelaksanaan

Kegiatan dilakukan pada hari senin, 15 Maret 2021 pukul 10.00 12.15. WIB

\section{HASIL DAN PEMBAHASAN}

Kegiatan penyuluhan berupa Edukasi Manfaat Jus Wortel Sebagai Terapi Nyeri Dismenorea Pada Remaja berjalan dengan lancar. Hal tersebut tidak lepas dari dukungan berbagai pihak. Sasaran kegiatan ini adalah seluruh remaja putri di Puskesmas Mulya Asri yang mengalami dismenore dan yang belum pernah mendapatkan penyuluhan tentang penanganan dismenore sebelumnya. Penyuluhan dilakukan dengan media leaflet, metode yang digunakan adalah ceramah, tanya jawab dan demonstrasi pembuatan jus wortel.

Berikut gambar pelaksanaan kegiatan

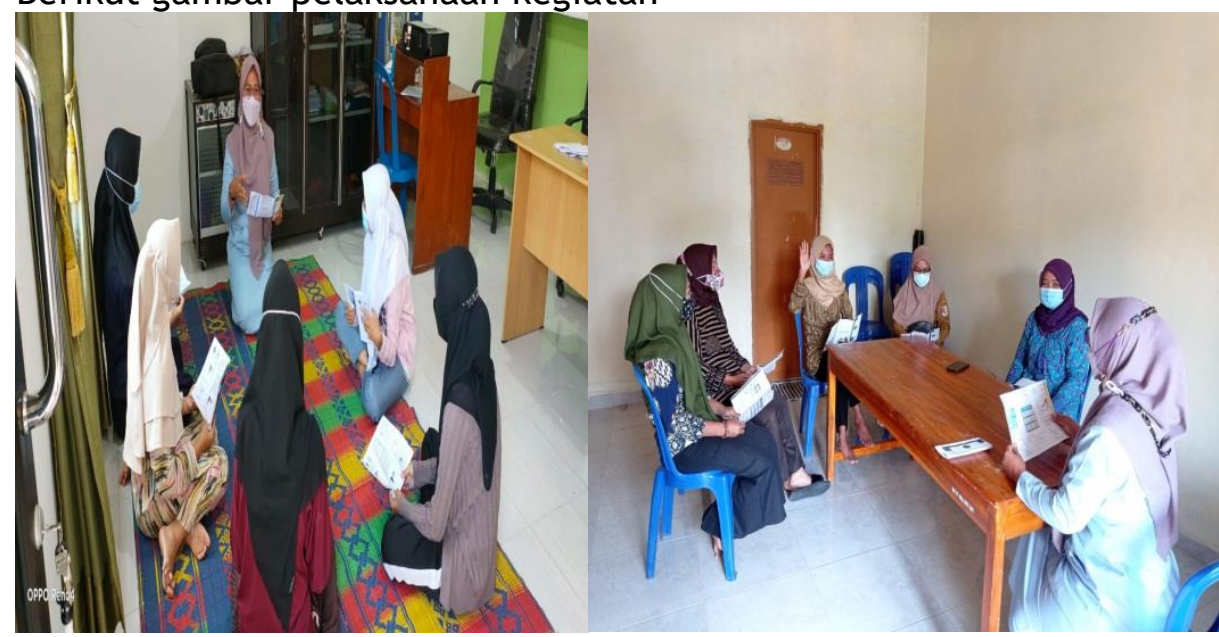

Gambar 4.1 Foto kegiatan Pengabdian Kepada Masyarakat

Materi disminore diberikan paling awal dengan tujuan agar remaja mengetahui fisiologi dismenore primer, tanda gejala, dampak serta beberapa terapi yang dapat digunakan dalam menurunkan keluhan tersebut. Lalu dilanjut dengan demontrasi pembuatan jus wortel. Pemateri menyarankan kepada remaja untuk komsumsi jus wortel $2 \mathrm{kali} /$ hari saat menstruasi, jus dapat dibuat dari 250 gr wortel segar. Pada akhir kegiatan tim melakukan evaluasi dengan memberikan beberapa pertanyaan kepada peserta, didapatkan $90 \%$ remaja mengerti dan faham tentang dismenore serta cara menanganinya. Dari hasil pretest dan post test diketahui terdapat peningkatan pengetahuan sebanyak $55 \%$.

Informasi dapat terserap dengan baik oleh responden dikarenakan edukasi diberikan dengan menggunakan berbagai media dan metode, dalam hal ini tim mengunakan metode ceramah dengan alat bantu berupa leaflet. Selain itu tim dapat memberikan contoh langsung cara pembuatan jus wortel kepada remaja, 
remaja lebih antusias sehingga materi dapat diterima secara maksimal. Remaja lebih mudah memahami materi terbukti dengan adanya peningkatan pengetahuan. Harapannya pengetahuan yang didapat menjadi dasar untuk berperilaku hidup sehat dengan menggunakan terapi yang tepat dan minim efek samping seperti penanganan dismenore dengan jus wortel.

\section{KESIMPULAN}

Dari hasil kegiatan Edukasi Manfaat Jus Wortel Sebagai Terapi Nyeri Dismenorea Pada Remaja di Puskesmas Mulya Asri dapat disimpulkan bahwa adanya peningkatan pengetahuan remaja putri tentang dismenore serta cara mengatasi dismenorea menggunakan jus wortel yaitu sebesar $55 \%$.

\section{DAFTAR PUSTAKA}

Affandy. (2021). Tetap Kreatif dan Inovatif di Tengah Pandemi Covid-19 (Jilid 4). Jawa Tengah: Nasya Expanding Management

Akbar, M. I. A., Tjokroprawiro, B. A., \& Hendarto, H. (2020). Ginekologi Praktis Komprehensif (Vol. 2). Airlangga University Press.

Al-Snafi AE.Arabian Medicinal Plants with Analgesic and Antipyretic Effects-Plant Based Review (Part 1). IOSR Journal of Pharmacy. www.iosrphr.org(e)ISSN:2250-3013.(p)-ISSN:2319-4219 Volume 8, Issue 6 Version 11(June 2018),Pp.81-102

Emilia, O., \& Prabandari, Y. S. (2019). Promosi kesehatan dalam lingkup kesehatan reproduksi. UGM PRESS

Judha, M., Sudarti, A. F. (2012) Teori Pengukuran Nyeri Dan Nyeri Persalinan.Yogyakarta : Nuha Medika

Hartati Bahar, F. L., \& Apriani, A. R. (2020). Menyusun Dan Mengembangkan Materi Penyuluhan Kesehatan. Spasi Media.

Heni Setyowati, E. R., \& Kp, S. (2018). Akupresur untuk kesehatan wanita berbasis hasil penelitian. Unimma press

Latifah, S., Mardiah, S. S., \& Kurniah, H. (2021). Pengaruh Pemberian Jus Wortel Terhadap Tingkat Nyeri Dysmenorhea Primer Pada Siswi Kelas Xi Sma Negeri 3 Tasikmalaya. IMJ (Indonesian Midwifery Journal), 4(2).

Priyatna, A. (2013). Be a smart teenager. Elex Media Komputindo

Puspita, N. L. M. (2018). Pengaruh Pemberian Jus Wortel Terhadap Nyeri Dismenorea Pada Remaja Putri: The Influence Of Carrot Juice And Avocado Juice To Dysmenorrhoea Pain In Adolescent Girls. Jurnal Ilmiah Kebidanan (Scientific Journal of Midwifery), 4(1), 14-19.) 